九州大学学術情報リポジトリ

Kyushu University Institutional Repository

\title{
Changes in Translatable RNA Population during Hardening of Chlorella ellipsoidea C-27
}

Joh, Toshio

Laboratory of Food Hygienic Chemistry, Faculty of Agriculture, Kyushu University

Yoshimoto, Makoto

Laboratory of Food Hygienic Chemistry, Faculty of Agriculture, Kyushu University

Honjoh, Ken-ichi

Laboratory of Food Hygienic Chemistry, Faculty of Agriculture, Kyushu University | Laboratory of Food Hygienic Chemistry, Faculty of Agriculture, Kyushu University

Mi yamoto, Takahisa

Laboratory of Food Hygienic Chemistry, Faculty of Agriculture, Kyushu University

他

https://doi.org/10.5109/24017

出版情報：九州大学大学院農学研究院紀要. 37 (3/4)，pp.257-263，1993-03. Kyushu University バージョン：

権利関係 : 


\title{
Changes in Translatable RNA Population during Hardening of Chlorella ellipsoidea C-27
}

\author{
Toshio J oh, M akoto Y oshimoto, K en-ichi H onjoh, \\ Takahisa M iyamoto and Shoji $\mathrm{H}$ atano
}

Laboratory of Food Hygienic Chemistry, Faculty of Agriculture, Kyushu University 46-09, Fukuoka 812, Japan

(Received October 30, 1992)

\begin{abstract}
The effects of hardening on gene expression in Chlorella ellipsoidea $\mathrm{C}$-27 were investigated. In vitro translation products of translatable poly(A)+RNA prepared from unhardened and hardened Chlorella cells were separated by SDS-polyacrylamide gel electrophoresis and two-dimensional polyacrylamide gel electrophoresis, and visualized by fluorography. A time course study showed that changes in profile of poly(A)+RNA occur from the 1st hour of hardening. A comparison of in vitro translation products from unhardened and 24-h hardened cells indicated that 13 polypeptides newly appear and 10 polypeptides increase in abundance during hardening. The results suggest that expression of specific genes is involved in the development of frost hardiness.
\end{abstract}

\section{INTRODUCTION}

Some plant species develop freezing tolerance when exposed to low nonfreezing temperature (Graham and Patterson, 1982; Guy, 1990). It is known that during this cold acclimation many physiological and biochemical changes occur in plant cells: alterations in lipid composition, increases of sugar and soluble protein content, and changes in enzyme activities (Graham and Patterson, 1982; Uemura and Yoshida, 1984; Calderon and Pontis, 1985; Lynch and Steponkus, 1987; Guy, 1990). Weiser (1970) has first suggested that the biochemical, biophysical, and physiological changes that occur in plant cells during cold acclimation involve the altered gene expression. This suggestion is now supported by evidences that cold acclimation-specific changes in mRNA and protein profiles are identified in a wide variety of higher plants (Guy, 1990; Thomashow, 1990). However, the functions of the cold-induced proteins and the molecular mechanisms regulating their changes are still unclear.

We previously have showed that hardened cells of Chlorella ellipsoidea C-27 are able to survive slow freezing to $-196^{\circ} \mathrm{C}$ (Hatano et al., 1976a), and the involvement of RNA and protein syntheses and lipid changes in the hardening process of the algal cells suggests the similarity of their hardening mechanism to that of higher plants (Hatano et al., 1976b; Hatano, 1978; Hatano et al., 1981, 1982). We also recently indicated alteration in profiles of in vivo soluble proteins during hardening of the strain C-27 (Yoshimoto et al., 1991). In order to further investigate the molecular genetic basis of frost hardiness, we analyzed in vitro translation products of poly(A) ${ }^{+}$RNA from unhardened and hardened cells.

This paper demonstrates that changes in gene expression at transcriptional level 
are involved in the development of frost hardiness of Chlorella ellipsoidea C-27.

\section{MATERIALS AND METHODS}

\section{Plant materials}

Chlorella ellipsoidea IAM C-27 was grown synchronously in the MC medium of Watanabe $(1960)$, at $25^{\circ} \mathrm{C}$, under $10 \mathrm{klux}$, with $1.3 \% \mathrm{CO}_{2}$ in air, at a concentration of about $1.0 \times 10^{10}$ cells per liter, under a 16-h light/B-h dark regime, as described previously (Hatano et al., 1976a). Inasmuch as the cells were hardened most at the $\mathrm{L}_{2}$ stage (an intermediate stage in the ripening phase of the cell cycle) (Hatano et al., 1976a), $\mathrm{L}_{2}$ cells were used here.

\section{$H$ ardening}

$\mathrm{L}_{2}$ cells synchronized at $25^{\circ} \mathrm{C}$ were directly hardened at $3^{\circ} \mathrm{C}$. During hardening, the culture was aerated with $1.3 \% \mathrm{CO}$, in air and kept in the light (10 klux). Portions of the cell culture were withdrawn at intervals and centrifuged at $1,000 \mathrm{X} \mathrm{g}$ for $5 \mathrm{~min}$ at $3^{\circ} \mathrm{C}$. After washing once with distilled water, cells were suspended in RNA extraction buffer (0.1 M Tris- $\mathrm{HCl}, \mathrm{pH} 9.0,0.1 \mathrm{M} \mathrm{NaCl}, 10 \mathrm{mM}$ EDTA, and 1\% SDS) at a concentration of about $1.5 \times 10^{9}$ cells $/ \mathrm{ml}$. The cell suspension was frozen in liquid nitrogen and stored at $-80^{\circ} \mathrm{C}$.

\section{I solation of poly $(\mathbf{A})^{+} \mathbf{R N A}$}

The frozen suspension was thawed at $4^{\circ} \mathrm{C}$ and to this an equal volume of phenol/ chloroform/isoamyl alcohol $(25: 24: 1, \mathrm{v} / \mathrm{v} / \mathrm{v})$ and 0.2 volumes of 2-mercaptoethanol were added. The mixture was homogenized with glass beads of $0.5 \mathrm{~mm}$ in diameter in a reciprocal shaker (Vibrogen-Zellmühle; Edmund Biihler Co., Ttibingen, F.R.G.), operated at $4,500 \mathrm{rpm}$ at $4^{\circ} \mathrm{C}$ for $12 \mathrm{~min}$. The homogenate was freed from the beads by passage through a sintered-glass funnel and the filtrate was centrifuged at 3,500X $\mathrm{g}$ for $10 \mathrm{~min}$ at $4^{\circ} \mathrm{C}$. The upper aqueous phase containing total nucleic acids was washed twice with an equal volume of phenol/chloroform/isoamyl alcohol to remove proteins and cell debris completely. Total nucleic acids were precipitated with 0.05 volumes of $5 \mathrm{M} \mathrm{NaCl}$ and 2.5 volumes of ethanol overnight at $-20^{\circ} \mathrm{C}$, washed with cold $70 \%$ ethanol and then dissolved in TE buffer (10 mM Tris- $\mathrm{HCl}, \mathrm{pH} 7.5,1 \mathrm{mM}$ EDTA). Total RNA was precipitated overnight at $4^{\circ} \mathrm{C}$ by the addition of $5 \mathrm{M} \mathrm{LiCl}$ to a final concentration of $2 \mathrm{M}$. Poly(A) ${ }^{+}$RNA was purified from the RNA by the use of an oligo(dT)-cellulose (Sigma, St. Louis, MO, U.S.A) as described by Maniatis et al. (1982).

\section{Analysis of in vitro translation products}

Poly (A) ${ }^{+}$RNA $(0.5$ to $1.0 \mu \mathrm{g})$ was translated by using a wheat germ extract in vitro translation kit (Boehringer Mannheim Yamanouchi, Tokyo, Japan) in the presence of $80 \mathrm{mM} \mathrm{CH}_{3} \mathrm{COOK}, 2 \mathrm{mM} \mathrm{Mg}\left(\mathrm{CH}_{3} \mathrm{COO}\right)_{2}$, and $2.2 \mathrm{MBq}$ of $\left[{ }^{35} \mathrm{~S}\right]$ methionine $(37 \mathrm{TBq} /$ mmol; Hungarian Academy of Sciences, Budapest, Hungary). The translation products were separated by the SDS-polyacrylamide gel electrophoresis (SDS-PAGE) procedure of Laemmli (1970) and by the two-dimensional polyacrylamide gel electrophoresis (2D-PAGE) procedure of O'Farrell(1975). Following electrophoresis, the gel 
was fixed, treated with $\mathrm{EN}^{3} \mathrm{HANCE}$ (NEN, Boston, MA, U.S.A), dried and then exposed to Kodak XAR-5 film with an intensifying screen at $-80^{\circ} \mathrm{C}$.

\section{RESULTS}

We previously reported changes in pattern of in vivo proteins during hardening in C. ellipsoidea C-27 (Yoshimoto et al., 1991). To confirm that these changes occur at transcriptional level, in vitro translation products of poly $(\mathrm{A})^{+} \mathrm{RNA}$ from hardened cells for various periods up to $24 \mathrm{~h}$ were analyzed. Figure 1 shows the results of SDSPAGE of the in vitro translated proteins. Polypeptides of 51, 47, 30, 26, 23, 18, and 15 $\mathrm{kDa}$ apparently increased during hardening (indicated by arrowheads on the right side), while polypeptides of 28 and $16 \mathrm{kDa}$ disappeared (arrowheads on the left side). Especially $47 \mathrm{kDa}$ polypeptide seemed to increase in a two-step process, that is, this polypeptide once increased at the 1st hour of hardening, but decreased at and after the 2nd hour of hardening, and then increased again after the 6th hour of hardening. Changes in the profiles of the translation products occurred from the 1 st hour of hardening, suggesting that response of gene expression to low temperature is relatively sensitive.

Furthermore, in vitro translation products from unhardened and 24-h hardened cells were analyzed in detail by 2D-PAGE. In Fig. 2, alphabetized and numbered spots

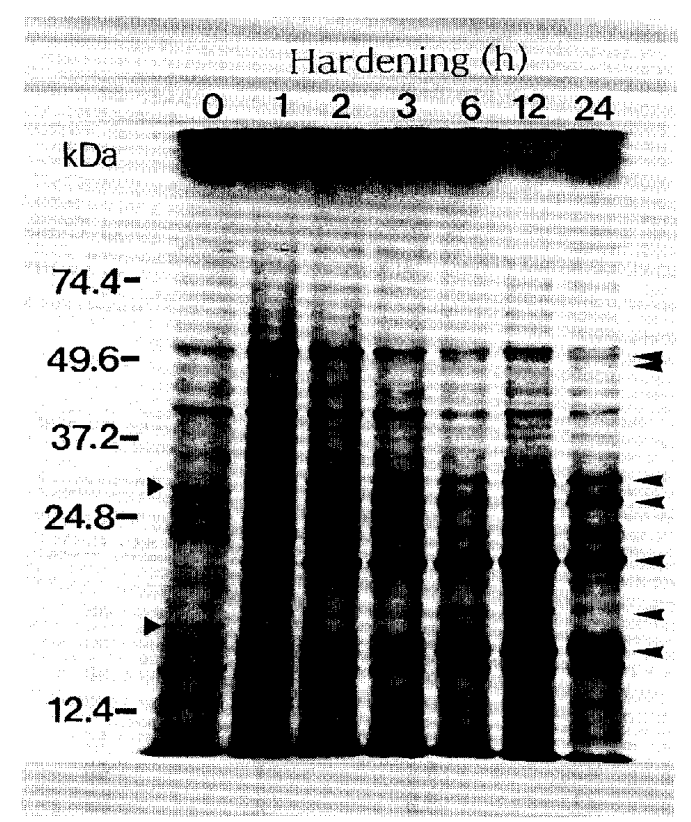

Fig. 1. Fluorograph of in vitro translation products from poly (A)+RNA of hardened cells for various periods. The $\left.{ }^{35} \mathrm{~S}\right]$ methionine-labeled translated proteins of $2 \times 10^{5}$ cpm were loaded in each lane and separated by $12.5 \%$ polyacrylamide gel containing $0.1 \%(\mathrm{w} / \mathrm{v})$ SDS. Arrowheads on the right and left sides of the electrophoregraph indicate bands of increasing and decreasing translated polypeptides during hardening, respectively. 




Fig. 2. 2D-PAGE patterns of in vitro translation products from poly $(\mathrm{A})^{+} \mathrm{RNA}$ of unhardened (A) and 24-h hardened (B) cells. Open circles and squares indicate spots of polypeptides which newly appeared and increased in abundance at the 24th hour of hardening, respectively.

Table 1. Analysis of in vitro translation products during hardening.

\begin{tabular}{cccccc}
\hline & Induced & \multicolumn{5}{c}{ Increased } \\
\hline spot* $^{*}$ & Mr (kDa) & PI & spot* $^{*}$ & Mr (kDa) & PI \\
\hline 1 & 74 & 5.3 & a & 65 & 5.3 \\
2 & 73 & 5.9 & b & 64 & 5.2 \\
3 & 71 & 5.1 & c & 50 & 5.9 \\
4 & 62 & 5.3 & d & 47 & 5.0 \\
5 & 45 & 6.6 & e & 44 & 6.8 \\
6 & 43 & 6.4 & f & 40 & 5.3 \\
7 & 41 & 5.9 & g & 37 & 5.3 \\
8 & 40 & 5.0 & h & 30 & 5.3 \\
9 & 40 & 5.8 & i & 23 & 5.4 \\
10 & 22 & 4.3 & j & 21 & 4.3 \\
11 & 18 & 4.3 & & & \\
12 & 15 & 6.2 & & & \\
13 & 14 & 7.3 & & & \\
\hline
\end{tabular}

*Spots are corresponding to Fig. 2. 
indicate polypeptides that newly appeared and increased in abundance during hardening, respectively. The results showed that at least $\mathbf{1 3}$ polypeptides newly appear and 10 polypeptides increase in abundance and some polypeptides decrease or disappear during hardening. The relative molecular masses and the isoelectric points of polypeptides that newly appeared and increased by a 24-h hardening were summarized in Table 1. Of these, 4 polypeptides (spots e, i, j, and 7) increased markedly by a 24-h hardening. These results suggest that at least 23 translatable poly(A)+RNA species are induced' at the 24th hour of hardening and the proteins encoded by them are involved in the hardening process.

\section{DISCUSSION}

It is known that expression of specific genes is involved in the development of frost hardiness in higher plants and proteins encoded by these genes play an important role in the hardening process (Guy, 1990; Thomashow, 1990). We previously reported alterations in profiles of invivo soluble and membrane proteins during hardening in $\mathrm{C}$. ellipsoidea C-27 (Yoshimoto et al., 1991). In order to confirm that these alterations in the Chlorella are involved in gene expression in the same way as higher plants, poly $(\mathrm{A})^{+} \mathrm{RNA}$ were prepared from hardened cells for various periods up to $24 \mathrm{~h}$ and the in vitro translation products were analyzed. As expected, changes in profiles of translation products during hardening were observed; 23 polypeptides newly appeared or increased in abundance at the 24th hour of hardening (Figure 2 and Table 1), suggesting that the development of frost hardiness in the Chlorella is also accompanied by expression of specific genes.

As compared the number of in vivo newly appeared or increased polypeptides during hardening with that of in vitro, there were 19 polypeptides in vivo as against 23 in vitro (Yoshimoto et al., 1991). As the molecular mass of the changed polypeptides ranged between 74 and $14 \mathrm{kDa}$ in vitro as against between 141 and $27 \mathrm{kDa}$ in vivo (Yoshimoto et al., 1991), in vivo changed polypeptides are larger than them of in vitro. Normally, in in vitro translation experiments proteins of high molecular mass seem to be troublesome to be synthesized and in other reports about in vitro translation proteins of high molecular mass can not be detected abundantly, either (Danyluk and Sarhan, 1990; Koga-Ban et al., 1991; Lee et al., 1991). Consequently, the difference in range of the molecular mass of the changed polypeptides between in vitro and in vivo may come from the problem of in vitro translation system itself. Also, in comparison of the molecular mass and the isoelectric point of the changed polypeptides between both, any polypeptide does not agree except one polypeptide (spot $h$ in Figure 2 and Table 1). Inside cells, some polypeptides translated from poly(A) ${ }^{+} \mathrm{RNA}$ are processed to become mature proteins. Therefore these disagreements are presumed to be attributable to post-translational modification of protein that occurs only in vivo.

Although proteins of high molecular mass could not be synthesized abundantly, 23 polypeptides newly appeared or increased in abundance during hardening in the Chlorella, showing that its development of frost hardiness involves expression of specific genes in the same as higher plants. Guy (1990) and Thomashow (1990) summarized many reports about changes in synthesis and accumulation of proteins 
during cold acclimation in plants. According to them, 16 polypeptides reported in tomato are the most numerous in the number of increased proteins during cold acclimation in one plant. As compared with that, the number of newly appeared or increased proteins in the Chlorella, 23 polypeptides, seems to be very abundant. Although, of course, all of these polypeptides would not be involved in the development of frost hardiness, the fact that in spite of unicellular plant (but maybe because of unicellular plant) such many changes in protein synthesis occur during hardening shows that a mechanism of the development of frost hardiness in the Chlorella may be somewhat different from that in higher plants.

\section{ACKNOWLEDGEMENTS}

The present research was supported by the Egashira Foundation for Promotion of the Hotel and the Restaurant Industry. We are grateful to Mr. Jun Funabashi and Mr. Yasumichi Mizota for technical support.

\section{REFERENCES}

Calderon, P. and Pontis, H. G. 1985 Increase of sucrose synthase activity in wheat plants after a chilling shock. Plant Science, 42: 173-176

Danyluk, J. and Sarhan, F. 1990 Differntial mRNA transcription during the induction of freezing tolerance in spring and winter wheat. Plant Cell Physiol., 31: 609-619

Graham, D. and Patterson; D. 1982 Responses of plants to low, nonfreezing temperatures: proteins, metabolism, and acclimation. Ann, Rev, Plant Physiol., 33: 347-372

Guy, C. L. 1990 Cold acclimation and freezing tolerance: role of protein metabolism. Ann. Rev. Plant Physiol. Plant Mol. Biol., 41: 187-223

Hatano, S. 1978 Studies on frost hardiness in Chlorella ellipsoidea: effects of antimetabolites, surfactants, hormones and sugars on the hardening process in the light and dark. In Plant cold Hardiness and Freezing Stress. Edited by Li, P. H. and Sakai, A. Academic Press, New York, pp. 175-196

Hatano, S., Kabata, K. and Sadakane, H. 1981 Transition of lipid synthesis from chloroplasts to a cytoplasmic system during hardening in Chlorella ellipsoidea. Plant Physiol., 67: 216-220

Hatano, S., Kabata, K., Yoshimoto, M. and Sadakane, H. 1982 Accumulation of free fatty acids during hardening of Chlorella ellipsoidea. Plant Physiol., 70: 1173-1177

Hatano, S., Sadakane, H., Tutumi, M. and Watanabe, T. 1976a Studies on frost hardiness in Chlorella ellipsoidea I. Development of frost hardiness of Chlorella ellipsoidea in synchronous culture. Plant Cell Physiol., 17: 451-457

Hatano, S., Sadakane, H., Tutumi, M. and Watanabe, T 1976b Studies on frost hardiness in Chlorella ellipsoidea II. Effects of inhibitors of RNA and protein synthesis and surfactants on the process of hardening. Plant Cell Physiol., 17: 643-651

Koga-Ban, Y., Abe, M. and Kitagawa, Y. 1991 Alteration in gene expression during cold treatment of rice plant. Plant Cell Physiol., 32: 901-905

Laemmli, U. K. 1970 Cleavage of structural proteins during the assembly of the head of bacteriophage T4. Nature, 227: 680-685

Lee, S. P., Chen, T. H. H. and Fuchigami, L. H. 1991 Changes in the translatable RNA population during abscisic acid induced freezing tolerance in bromegrass suspension culture. Plant Cell Physiol., 32: 45-56

Lynch, D. V. and Steponkus, P. L. 1987 Plasma membrane lipid alterations associated with cold 
acclimation of winter rye seedlings (Secale cereale L. cv Puma). Plant Physiol., 83: 761-767 Maniatis, T., Fritsch, E. F. and Sambrook, J. 1982 Molecular Cloning: a Laboratory Manual. Cold Spring Harbor Laboratory Press, Cold Spring Harbor, New York

O'Farrell, P. H. 1975 High resolution two-dimensional electrophoresis of proteins. J. Biol. Chem., 19: $4007-4021$

Thomashow, M. F. 1990 Molecular genetics of cold acclimation in higher plants. Adv. Genet., 28: 99-131

Uemura, M. and Yoshida, S. 1984 Involvement of plasma membrane alterations in cold acclimation of winter rye seedlings (Secale cereale L. cv Puma). Plant Physiol., 75: 818-826

Watanabe, A. 1960 List of algal strains in collection at the Institute of Applied Microbiology, University of Tokyo. J. Gen. Appl.Microbiol., 6: 283-292

Weiser, C. J. 1970 Cold resistance and injury in woody plants. Science,, 169: 1269-1278

Yoshimoto, M., Okamura, H., Joh, T., Miyamoto, T. and Hatano, S. 1991 Changes in soluble and membrane proteins of Chlorella ellipsoidea during early time of hardening. J. Fac. Agr., Kyushu Univ., 36 (1, 2): 69-77 